УДК 338.22.021.1

О. П. Недоспасова

Национальный исследовательский

Толский политехнический университет, 2. Толск, Российская Федерация

Е. А. Ефремова

Национальный исследовательский толский политехнический университет, 2. Толск, Российская Федерация

А. А. Сондор

Национальный исследовательский Толский политехнический университет, г. Толск, Российская Федерация

К. И. Хайдарова

Национальный исследовательский

толский политехнический университет, 2. Толск, Российская Федерация

А. А. Недоспасов

Северский технологический институт - филиал «Национального исследовательского ядерного университета “МИФИ”"

2. Северск Толской области, Российская Федераиия

\title{
ФРАНЧАЙЗИНГ ДЛЯ СОЦИАЛЬНЫХ ПРОЕКТОВ: ЧЕМУ МОЖНО НАУЧИТЬСЯ У БИЗНЕСА?
}

\begin{abstract}
АннотАция. Актуальность исследования определяется тем, что в настоящее время даже самые развитые страны не способны осуществлять эффективную социальную политику, опираясь только на бюджетные источники. Мировая практика последних лет показывает, что в данную сферу все активнее привлекаются корпоративные ресурсы, благотворительные взносы граждан и организаций, создаются государственно-частные партнерства, развивается социальное предпринимательство, в том числе на основе франчайзинга. Последнее из названных направлений (социальный франчайзинг) гарантирует не только воспроизводство найденного эффективного решения социальной проблемы как типового, но и перенос положительного опыта с одной территории на другую, позволяет рационально объединить ресурсы различных инвесторов (в том числе государства и бизнес-структур), сократить время на реализацию проекта, оптимизировать затраты, гарантировать высокое качество социально-значимого продукта или услуги. В статье обосновывается необходимость, возможность и целесообразность применения экономического механизма франчайзинга (как особой формы ведения бизнеса) для решения многих социальных проблем современного общества.

КЛЮчЕВЫЕ СЛОВА. Социальная политика; государственно-частное партнерство; франчайзинг; благополучие; эффективность.

ФИНАНСИРОВАНИЕ. Исследование выполнено на базе Томского политехнического университета при финансовой поддержке Министерства образования и науки Российской Федерации в рамках выполнения научно-исследовательских работ по направлению «Оценка и улучшение социального, экономического и эмоционального благополучия пожилых людей», договор № 14.Z50.31.0029.

ИНФОРМАЦИЯ О СТАТЬЕ. Дата поступления 12 февраля 2017 г.; дата принятия к печати 2 марта 2017 г., дата онлайн-размещения 31 марта 2017 г.
\end{abstract}

\section{Baikal Research Journal}


O. P. Nedospasova

National Research Tomsk Polytechnic University, Tomsk, Russian Federation

E. A. Efremova

National Research Tomsk Polytechnic University, Tomsk, Russian Federation

A. Sondor

National Research Tomsk Polytechnic University, Tomsk, Russian Federation

K. I. Khaidarova

National Research Tomsk Polytechnic University, Tomsk, Russian Federation

A. A. Nedospasov Seversk Technological Institute, National Research Nuclear University "MIFI", Seversk, Russian Federation

\title{
FRANCHISING FOR SOCIAL PROJECTS: WHAT CAN WE LEARN FROM BUSINESS?
}

\begin{abstract}
The thematic justification of the study is determined by the fact that at the present time even the most developed countries are not able to carry out an effective social policy, relying only on the budgetary resources. The world practice of the recent years has shown that this area is more actively attracting corporate resources, donations of citizens and organizations, brings into being public-private partnership (PPP), develops social entrepreneurships, including the ones based on franchising.

The latter of the named directions (social franchising) guarantees not only reproduction of the effective solution found for a social problem as being typical. Also, it can guarantee transfer of good practice from one territory to another, allows to rationally pool the resources of various investors (including government and business structures), to reduce the time for implementing a project, to optimize costs, to ensure high quality of socially significant product or service. The article substantiates the necessity, opportunity and practicability of using the economic mechanism of franchising (as a special form of doing business) to solve many social problems of the modern society.

KEYWORDS. Social policy; public-private partnerships; franchising; welfare; efficiency. FINANCING. The research was carried out on the basis of the Tomsk Polytechnic University with the financial support of the Ministry of Education and Science of the Russian Federation in the framework of carrying out research work in the field of «Assessment and improvement of social, economic and emotional well-being of elderly people», agreement No. 14.Z50.31.0029.

ARTICLE INFO. Received February 12, 2017; accepted March 2, 2017; available online March 31, 2017.
\end{abstract}

Как известно, Россия является одной из самых богатых стран мира по запасам природных ресурсов. Запасы нефти в нашей стране по сравнению с Западной Европой в подушевом исчислении больше в 34,9 раза, газа — в 17,9 раза; угля — в 15,8 раза, леса - в 26,6 раза [1, с. 47-52]. Несмотря на масштабность природного богатства $11 \%$ населения РФ (16,1 млн человек) живут за чертой бедности ${ }^{1}$. Столь вопиющее и на первый взгляд парадоксальное социально-экономическое противоречие является одной из наиболее острых тем для дискуссий как в российском,

${ }^{1}$ Федеральная служба государственной статистики (Росстат) [Электронный ресурс] : офиц. сайт. URL: http://www.gks.ru/wps/wcm/connect/rosstat_main/rosstat/ru/statistics/population/level/\#.

\section{Baikal Research Journal}


так и международном экспертном сообществе. Не вдаваясь в смысловые сюжеты таких дискуссий, отметим, что произошедшее в 2016 г. снижение реальных доходов населения почти на $6 \%^{2}$ не только обострило проблему неравенства в потреблении и усугубило поляризацию общества на богатых и бедных, но и актуализировало необходимость изменений в социальной политике, существенного усиления тех ее мер, которые направлены на материальную поддержку наиболее уязвимых слоев населения. Дополнительным аргументом к скорейшим шагам Правительства РФ в этом направлении является необходимость безусловного выполнения требований Международного пакта об экономических, социальных и культурных правах, принятого мировым сообществом еще в 1966 г. и вступившим в силу в нашей стране в 1976 г., где в ст. 11 записано, что «государства признают право каждого на достаточный жизненный уровень для него и его семьи, включающий достаточное питание, одежду и жилище, и на непрерывное улучшение условий жизни» ${ }^{3}$. Таким образом, современная социальная политика, независимо от фактических показателей экономической динамики и (или) экономической стабильности должна быть действенным средством поддержания устойчивого равновесия между различными социальными группами, дифференцированными по уровню потребления и, соответственно, жизненному уровню. Основные направления социальной политики хорошо известны. Они включают гарантию конституционных прав граждан в области труда, социальной защиты населения, образования, охраны здоровья, культуры, обеспечения жильем, решение проблем труда и социального развития, повышение уровня жизни населения, обеспечение роста доходов населения, доступность социальных благ, борьбу с бедностью и защиту социально уязвимых слоев населения и ряд других важных направлений [2, с. 355].

Осуществление широкого комплекса мероприятий в социальной сфере является для России, безусловно, важнейшим национальным приоритетом. Об этом убедительно говорят данные, представленные на рис. 1.

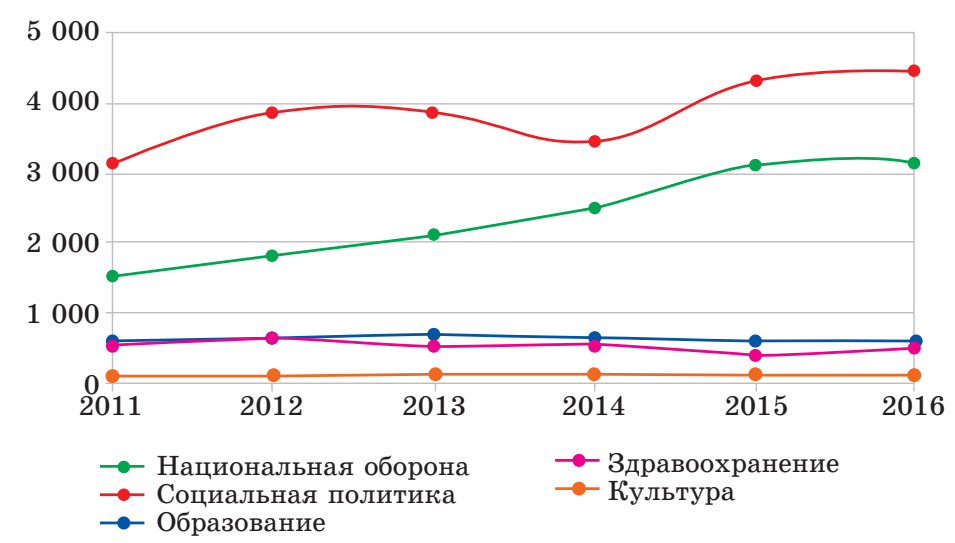

Рис. 1. Фактические расходы Федерального бюджета (отдельные статьи), млрд р. Составлено по официальным данным РОССТАТА

Бюджетные расходы на осуществление социальной политики являются в нашей стране более значимыми, чем расходы на национальную оборону, а их сумма в последние 2 года (после некоторого снижения в 2013 и 2014 гг.) возросла,

${ }^{2}$ Росстат [Электронный ресурс]. URL: http://www.gks.ru/wps/wcm/connect/rosstat_main/rosstat/ $\mathrm{ru} /$ statistics/population/.

${ }^{3}$ United Nations [Electronic resource]. Treaty Series. Vol. 993. P. 35-43. URL: http://www.un.org/ $\mathrm{ru} /$ documents/decl_conv/conventions/pactecon.

\section{Baikal Research Journal}


достигнув в 2016 г. 4500 млрд р. Планы Правительства на ближайшие три года (рис. 2) предусматривают, что социальные расходы в Федеральном бюджете увеличатся и превысят сумму в 5000 млрд р.

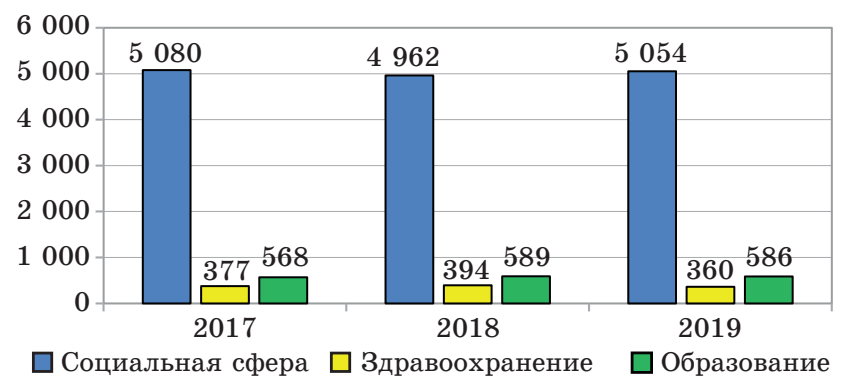

Рис. 2. Предполагаемые расходы Федерального бюджета на социальную сферу, млрд р.

Составлено авторали по официальным данным РОССТАТА

Такая динамики выглядит очень обнадеживающе, однако, «магия больших цифр», увы, не гарантирует социально-экономической стабильности и благополучия каждому члену общества. Как известно, численность населения РФ с доходами ниже прожиточного минимума в общей численности не только остается весьма значительной, но и увеличивается (рис. 3).

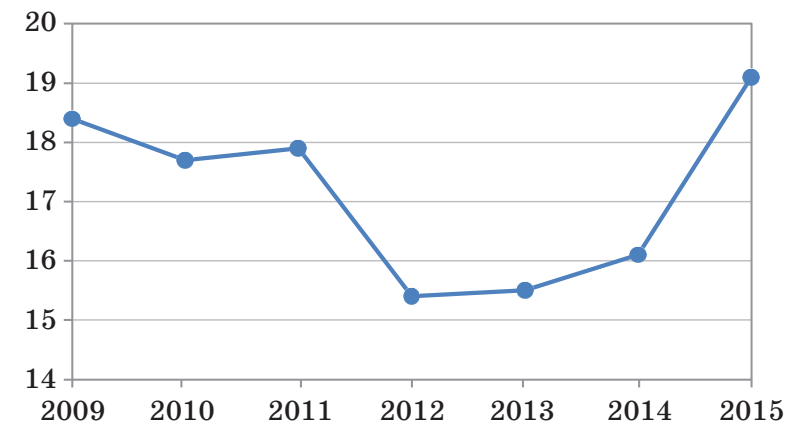

Рис. 3. Численность населения в иелом по России с денежными доходами ниже величины прожиточного минимула, млн чел.

Составлено авторами по официальным данным РОССТАТА

Сказанное позволяет сделать вывод о том, что без действенного и эффективного механизма поддержания устойчивого равновесия между группами людей с разным уровнем потребления и разным жизненным уровнем социальная политика (даже на фоне существенного прироста социальных расходов) в значительной мере ущербна, она не обеспечивает выполнения требований статьи 25 «Всеобщей декларации прав человека», в которой говорится, что "Каждый человек имеет право на такой жизненный уровень, включая пищу, одежду, жилище, медицинский уход и необходимое социальное обслуживание, который необходим для поддержания здоровья и благосостояния его самого и его семьи, и право на обеспечение на случай безработицы, болезни, инвалидности, вдовства, наступления старости или иного случая утраты средств к существованию по не зависящим от него обстоятельствам» ${ }^{4}$.

4 United Nations [Electronic resource]. URL: http://www.un.org/ru/documents/decl_conv/ declarations/declhr.shtml/.

\section{Baikal Research Journal}


Сказанное актуализирует задачу поиска дополнительных ресурсов для решения острых социальных проблем российского общества, необходимости использования новых инструментов, обеспечивающих не только сохранение, но и повышение уровня социально-экономического благополучия отдельных семей и личностей. Большой интерес в этом направлении представляет использование возможностей государственно-частного партнерства (ГЧП) как системы договорного взаимодействия государства и бизнеса для решения общественно значимых (и прежде всего социальных) задач на взаимовыгодных условиях ${ }^{5}$. Современные формы такого партнерства хороши известны как в мировой практике, так и в России. В зависимости от характера решаемых в рамках ГЧП конкретных задач все множество существующих и вновь возникающих форм партнерств можно сгруппировать по их соответствию определенным базовым моделям [3-5]. Их отдельные элементы могут давать новые сочетания, востребованные для решения специфических задач, в том числе при формировании ГЧП для решения важных задач в области социальной политики [6-8]. Отметим, что ГЧП не является изобретением последнего времени. История дореволюционной России наполнена позитивным опытом эффективного взаимодействия государства и бизнеса. Здесь достаточно вспомнить строительство железнодорожной ветки из Петербурга в Царское Село (1836 г.), создание интервенционного биржевого синдиката для поддержания котировок российских ценных бумаг на Петербургской бирже (20 октября 1899 г.) [9, с. 34], концессионное освоение Маньчжурии (1897-1901 гг.), формирование (при поддержке С. Ю. Витте) в начале XX в. сети коммерческих учебных заведений и многие другие.

Кроме непосредственного объединения ресурсов бизнеса и государства, характерного для ГЧП, особого внимания для решения актуальных проблем в социальной сфере заслуживает, на наш взгляд, опыт заимствования успешных бизнес-решений на основе франчайзинга $[10 ; 11]$. Суть франчайзинга (в России он носит официальное название коммерческой концессии) Гражданский кодекс РФ излагает следующим образом. Компания, имеющая опыт работы в определенной отрасли экономики (правообладатель или франчайзер), передает другой коммерческой организации или предпринимателю (пользователю или франчайзи) право на использование своего фирменного наименования и (или) коммерческого обозначения, на охраняемую коммерческую информацию, а также на другие предусмотренные договором объекты исключительных прав - товарный знак, знак обслуживания и т. д. Пользователь, в свою очередь, обязуется выплачивать за это вознаграждение - роялти. Такой договор может заключаться на любой срок или быть бессрочным 6 .

Как известно, при данной форме организации бизнеса, компания-франчайзер предоставляет компании-франчайзи или человеку право продавать свой товар или услуги. Таким образом франчайзи получает право ассоциировать себя с брендом компании, применять отлаженные механизмы сбыта и маркетинговую стратегию, а в обмен соблюдает правила ведения бизнеса, установленные франчайзером. Франчайзи, как правило, оплачивает первоначальный взнос и в дальнейшем ежемесячные (или ежеквартальные) взносы франчайзеру. Если проводить аналогии с нашей жизнью, то франшиза схожа с арендой, так как используемый бренд

${ }^{5}$ О государственно-частном партнерстве, муниципально-частном партнерстве в Российской Федерации и внесении изменений в отдельные законодательные акты Российской Федерации : федер. закон от 13 июля 2015 г. № 224-ФЗ // Собрание законодательства РФ. 2015. № 29, ч. І. Ст. 4350.

${ }^{6}$ Гражданский кодекс Российской Федерации [Электронный ресурс] : федер. закон (часть вторая) от 26 янв. 1996 г. № 14-ФЗ (ред. от 23 мая 2016 г.). Ст. 1027. Договор коммерческой концессии // СПС «КонсультантПлюс».

\section{Baikal Research Journal}

электронный научный журнал Байкальского государственного университета 
никогда не станет собственностью франчайзи, а за его использование взымается плата. Взамен франчайзи предоставляется франчайзинговый пакет, который предоставляет предпринимателю все необходимые инструменты для развития бизнеса, что позволяет даже неопытному человеку весьма успешно вести дела своей новоиспеченной компании [12, с. 13]. Формы франчайзинга весьма разнообразны и могут быть отнесены к той или иной классификационной группе в зависимости от вида деятельности, количества франшиз, стратегии расширения, структуры построения сети, места франшизодателя в структуре сбытового канала (табл. 1).

Таблица 1

Классификация основных форм франчайзинга

\begin{tabular}{|l|l|}
\hline \multicolumn{1}{|c|}{ Признак } & \multicolumn{1}{|c|}{ Формы франчайзинга } \\
\hline По виду деятельности & $\begin{array}{l}\text { Товарный франчайзинг (на продажу готового товара). } \\
\text { Производственный франчайзинг (на производство товара). } \\
\text { Сервисный франчайзинг (на определенный вид деятельности, } \\
\text { франчайзинг бизнес-формата») }\end{array}$ \\
\hline По количеству франшиз & $\begin{array}{l}\text { Франчайзинг отдельно взятого предприятия. } \\
\text { Корпоративный франчайзинг }\end{array}$ \\
\hline $\begin{array}{l}\text { По стратегии расшире- } \\
\text { ния бизнеса }\end{array}$ & $\begin{array}{l}\text { Классический франчайзинг на условиях опциона. } \\
\text { Конверсионный франчайзинг. } \\
\text { Дочерний франчайзинг. } \\
\text { Франчайзинговый контракт на менеджмент }\end{array}$ \\
\hline $\begin{array}{l}\text { По структуре построения } \\
\text { франшизной сети }\end{array}$ & $\begin{array}{l}\text { Индивидуальный. } \\
\text { Районный франчайзинг }\end{array}$ \\
\hline $\begin{array}{l}\text { По месту франшизодате- } \\
\text { ля в структуре сбытового } \\
\text { канала }\end{array}$ & $\begin{array}{l}\text { Система типа «производитель - розничный торговец». } \\
\text { Система типа «производитель - оптовый торговец». } \\
\text { Система типа «попоставщик услуги - розничный торговец» }\end{array}$ \\
\hline
\end{tabular}

Отметим, что франчайзинг (как и любая другая форма организации бизнеса) имеет свои достоинства и недостатки, в том числе с точки зрения отдельных экономических субъектов, участвующих в данной форме взаимодействия (табл. 2). Однако то, что франчайзинг является эффективным инструментом развития малого бизнеса, своего рода «школой» для предпринимателей, помогает создавать новые рабочие места и привлекать инвестиций, способствует развитию внешней и внутренней торговли говорит о его высокой социально-экономической значимости на уровне национальной экономической системы в целом [13].

Анализ показал, что большинство положительных черт, характерных для коммерческого франчайзинга, оказывается весьма важными аргументами для принятия решения о выборе аналогичного формата взаимодействия для так называемого "социального франчайзинга» как особой формы взаимодействия с партнерами и (или) потребителям при предоставлении социально-значимых товаров, работ и услуг ${ }^{7}$. Социальный франчайзинг как в отечественной, так и в международной практике, принято рассматривать как эффективный способ решения (или смягчения) социальных проблем, осуществления социального предпринимательства и развития социальной сферы. Социальная франшиза, как и коммерческая представляет собой это набор благ и (или) методов ведения социального бизнеса, товарные знаки, технологии, полезные модели и ноу-хау. Все эти объекты (в том числе интеллектуальная собственность) передаются социальному франчайзи с целью решения социальных проблем, производства общественного блага, тиражирования успешных социальных практик, сохранения качества и уровня оказания социальной услуги или товара. При этом часто можно встретить социальные

\footnotetext{
${ }^{7}$ Они выделены в табл. 2 курсивом.
}

\section{Baikal Research Journal}

электронный научный журнал Байкальского государственного университета 
франшизы, при которых (в отличие от коммерческой) за нее платит не франчайзи, а франчайзер, либо плата выражается в гарантии объема производства общественного блага для определенных целевых аудиторий. На практике успешно реализуются разнообразные социальные франшизы: со вступительным взносом, платежами, привязанными к периоду пользования франшизой или объему производства товаров и услуг. Она может быть как в полной мере коммерческой, так и субсидированной (позволяющей снизить цены на товары и услуги), а также полностью некоммерческой (нацеленной исключительно на распространение лучшей социально-значимой практики, без взносов и стремления к прибыли).

Таблица 2

\section{Преимущества и недостатки коммерческого франчайзинга} для различных субъектов

\begin{tabular}{|c|c|c|}
\hline Субъекты & Преимущества франчайзинга & Недостатки франчайзинга \\
\hline Франчайзер & $\begin{array}{l}\text { Большие возможности по масштабирова- } \\
\text { нию бренда и расширению сети. } \\
\text { Региональная экспансия. } \\
\text { Повышение прибыли. } \\
\text { Возможны поставки собственных материа- } \\
\text { лов для франчайзи. } \\
\text { Не нужна дополнительная мотивация } \\
\text { франчайзи }\end{array}$ & $\begin{array}{l}\text { Недобросовестное поведение одного } \\
\text { из предприятий может сказаться } \\
\text { на имидже всего бренда. } \\
\text { Трудности контроля соблюдения } \\
\text { всех условий договора. } \\
\text { Проблемы сохранения коммерче- } \\
\text { ской тайны и конфиденциальности }\end{array}$ \\
\hline Франчайзи & $\begin{array}{l}\text { Получение готовой бизнес-модели предпри- } \\
\text { ятия с надежной стратегией развития. } \\
\text { Право на использование известной торго- } \\
\text { вой марки. } \\
\text { Информационная и методическая под- } \\
\text { держка. } \\
\text { Повышение конкурентоспособности. } \\
\text { Масштабные рекламные возможности. } \\
\text { Доступ к кредитным ресурсам }\end{array}$ & $\begin{array}{l}\text { Высокая конкуренция ввиду легко- } \\
\text { сти открытия предприятия. } \\
\text { Невозможность выйти из бизнеса в } \\
\text { случае неудачи. } \\
\text { Успех каждого предприятия фран- } \\
\text { чайзи напрямую зависит от успеха } \\
\text { франчайзера }\end{array}$ \\
\hline Клиент & $\begin{array}{l}\text { Получение качественных товаров и обслу- } \\
\text { живания. } \\
\text { Известнал торговая марка вызывает до- } \\
\text { верие у потребителя и является гарантом } \\
\text { качественных товаров и услуг. } \\
\text { Уверенность в качестве продукиии и } \\
\text { услуг, а также легкая идентификация по } \\
\text { единому стилю }\end{array}$ & $\begin{array}{l}\text { Франчайзинг снижает конкурен- } \\
\text { цию, что может снизить качество } \\
\text { товара и ограничить выбор. } \\
\text { Если франчайзи не справляется со } \\
\text { своей деятельностью или не следу- } \\
\text { ет условиям договора, то качество } \\
\text { предлагаемых товаров и услуг } \\
\text { может снизиться }\end{array}$ \\
\hline
\end{tabular}

Мировой опыт социального франчайзинга очень убедителен. Его началом можно считать открытие Флоренс Найтингель в 1860 г. школы для сестер милосердия при больнице Святого Фомы в Лондоне. Флоренс отдала на ее организацию деньги, собранные в Англии по специальной подписке. Известно, что вскоре выпускницы этой школы начали создавать аналогичные учреждения при других больницах и даже в других странах [14, с. 57]. Таким образом, Ф. Найтингейл явилась основательницей не только специализированного училища для медицинских сестер, но и системы профессионального ухода за больными людьми, предложив его (как лучшую для того времени практику) для широкого некоммерческого тиражирования. Последователями Флоренс в наши дни являются, например, сотрудники Шотландской компании «Caring Christmas Trees». Они занимаются выращиванием и продажей рождественских елок, направляя собранные деньги на поддержку бездомных. Их социальная франшиза хорошо известна в мире и получила распространение далеко за пределами Шотландии ${ }^{8}$. Социаль-

\footnotetext{
${ }^{8}$ Caring Christmas Trees [Electronic resource]. URL: https://www.caringchristmastrees.com/.
}

\section{Baikal Research Journal}


ная франшиза «Living Goods» нацелена на распространение знаний о здоровом образе жизни, товаров и лекарств, позволяющих его поддерживать. Некоммерческие организации, работающие на ее основе по всему миру, в том числе в беднейших районах Африки, ежегодно спасают множество жизней ${ }^{9}$. Еще одним примером социального франчайзинга является развитие сети ресторанов «Fifteen», где молодые безработные бесплатно обучаются поварским навыкам. Эта идея распространилась в Европе как модель социального франчайзинга, поддержанная государственными структурами. Сейчас рестораны «Fifteen» хорошо известны не только в Корнуолле (Великобритания), но и в Амстердаме (Нидерланды), Мельбурне (Австралия) и других городах мира. Отметим, что рестораны данного формата уже начали свою работу в Москве и Санкт-Петербурге ${ }^{10}$. Социальный франчайзинг, продвигаемый международной компании «Senior Group» имеет целью достижение максимального качества и доступности негосударственных услуг для пожилых людей. Многолетний опыт работы с партнерами из Израиля гарантирует соблюдение международных стандартов ухода за пожилыми людьми с нарушением памяти, старческой деменцией, в том числе страдающих болезнью Альцгеймера. Действуют программы профессионального восстановления и социальной реабилитации пожилых людей после инсульта, инфаркта, перелома шейки бедра и переломов конечностей. Все объекты «Senior Group» (независимо от страны их расположения) оснащены специальным оборудованием, лифтами-подъемниками, средствами малой инвалидной техники, функциональными кроватями, поручнями, которые создают безопасную среду для пожилых людей с ограниченной мобильностью, успешно адаптирована и работает международная система оценки качества работы пансионов ${ }^{11}$.

Отметим, что в России для помощи пожилым людям активно развивается не только сеть пансионатов компании «Senior Group». В течение последних девяти лет по принципу социальной франшизы создана отечественная сеть пансионатов для пожилых людей «Опека» (8 пансионатов в Москве, Санкт-Петербурге и Ленинградской области), где современный дизайн сочетается с высочайшим (отвечающим европейским стандартам) уровнем обслуживания ${ }^{12}$. Важно не только то, что благодаря обеспечению ухода за пожилыми близкими «Опека» изменила к лучшему жизнь более 3000 российских семей, но и то, что ее представители приняли активное участие в разработке закона «Об основах социального обслуживания граждан в Российской Федерации» ${ }^{13}$, который обеспечивает частичную компенсацию затрат на проживание в таких пансионатах со стороны государства.

Спектр областей, в которых применяется социальный франчайзинг в России в последние годы активно расширяется и охватывает различные виды деятельности: от открытия хосписов и частных домов престарелых до строительства тактильных оздоровительных дорожек в городских парках. Некоторые отечественные примеры успешных социальных франшиз представлены в табл. 3 .

Приведенные в табл. 3 примеры успешного тиражирования лучших практик социальной франшизы в России внушают надежду на хорошие перспективы дальнейшего расширения данного опыта. Однако нельзя не сказать и о препятствиях для развития социального франчайзинга. Наиболее серьезными из них являются отсутствие единой системы аттестации и стандартов соответствия для

\footnotetext{
${ }^{9}$ Living Goods [Electronic resource]. URL: https://livinggoods.org/.

${ }^{10}$ Fifteen [Electronic resource]. URL: http://www.fifteen.net/.

${ }^{11}$ Senior Group [Electronic resource]. URL: http://www.seniorgroup.ru/.

12 Опека [Электронный ресурс] : офиц. сайт социального гериатрического центра. URL: https:// sgc-opeca.ru/spb/.

${ }_{13}$ Об основах социального обслуживания граждан в Российской Федерации : федер. закон от 28 дек. 2013 г. № 442-Ф3 // Собрание законодательства РФ. 2013. № 52, ч. І. Ст. 7007.
}

\section{Baikal Research Journal}


социальных франшиз, трудности со сбором официальной статистики, не создана система обучения франчайзинговым отношениям в социальной сфере, отсутствует законодательная инициатива по разработке закона о социальном франчайзинге, нет стройной системы налоговых льгот для организаций, практикующих данный вид деятельности, нет сети учебно-консультационных центров по социальному франчайзингу [15].

Таблица 3

Прилеры успешных социальных франшиз, действующих в РФ

\begin{tabular}{|c|c|c|}
\hline Название & Сфера деятельности & $\begin{array}{c}\text { Территория, } \\
\text { год создания, сайт }\end{array}$ \\
\hline $\begin{array}{l}\text { Сеть } \\
\text { магазинов } \\
\text { «Спасибо!» }\end{array}$ & $\begin{array}{l}\text { Люди могут сдать бывшую в употреблении одежду, } \\
\text { после чего } 90 \% \text { общего количества распределяется } \\
\text { по благотворительным организациям и раздаются } \\
\text { нуждающимся, а } 10 \text { \% вещей отправляются в } \\
\text { магазины «Спасибо!», где продаются. Оставшаяся } \\
\text { после покрытия всех статей расходов прибыль } \\
\text { перечисляется на благотворительность }\end{array}$ & $\begin{array}{l}\text { Санкт-Петербург, } \\
\text { 2010, spasiboshop.org/ }\end{array}$ \\
\hline $\begin{array}{l}\text { Социальный } \\
\text { центр } \\
\text { «Авантаж» }\end{array}$ & $\begin{array}{l}\text { Центр приема и выдачи вещей, куда можно принести } \\
\text { ненужные, а нуждающиеся могут их получить } \\
\text { бесплатно, а также благотворительный магазин }\end{array}$ & $\begin{array}{l}\text { Томск, 2015, vk.com/ } \\
\text { avantagebutik }\end{array}$ \\
\hline $\begin{array}{l}\text { Фонд помощи } \\
\text { хосписам } \\
\text { «Вера» }\end{array}$ & $\begin{array}{l}\text { Оказывает помощь в обеспечении хосписов } \\
\text { медицинским оборудованием, средствами по уходу. } \\
\text { Поддерживает их пациентов, родственников, } \\
\text { сотрудников, занимается обучением персонала. }\end{array}$ & $\begin{array}{l}\text { Россия, 2006, } \\
\text { hospicefund.ru }\end{array}$ \\
\hline $\begin{array}{l}\text { Проект «Так } \\
\text { просто» }\end{array}$ & $\begin{array}{l}\text { Проект Агентства социальной информации, } \\
\text { позволяющий добровольцам, желающих стать } \\
\text { волонтерами реализовать себя. Проект создал } \\
\text { и поддерживает базу НКО и инициатив, } \\
\text { предоставляющих волонтерские возможности в более } \\
\text { чем } 250 \text { населенных пунктах России } \\
\end{array}$ & $\begin{array}{l}\text { Россия, } 2013, \\
\text { tak-prosto.org }\end{array}$ \\
\hline $\begin{array}{l}\text { Проект } \\
\text { «Стало мало» }\end{array}$ & $\begin{array}{l}\text { Детский магазин, позволяющий покупать и продавать } \\
\text { бывшие в употреблении детские вещи по доступным } \\
\text { ценам, а также клуб «Между нами мамами», } \\
\text { объединяющий матерей для взаимопомощи, активной } \\
\text { социальной жизни, участия в мастер-классах и } \\
\text { семинарах, направленных на самореализацию, а } \\
\text { также на совместное времяпрепровождение с детьми }\end{array}$ & $\begin{array}{l}\text { Россия (7 регионов), } \\
\text { 2013, stalomalo.ru }\end{array}$ \\
\hline $\begin{array}{l}\text { Фонд } \\
\text { «Помогать } \\
\text { легко» и } \\
\text { мульт-сериал } \\
\text { «Летающие } \\
\text { звери» }\end{array}$ & $\begin{array}{l}\text { «Помогать Легко» - это фонд помощи и содействия } \\
\text { детям в трудных жизненных ситуациях. Задача } \\
\text { фонда сделать благотворительность простой и } \\
\text { повседневно доступной для максимального числа } \\
\text { людей. С этой целью создан благотворительный } \\
\text { бренд «Летающие звери». Это популярный детский } \\
\text { мультипликационный сериал, разного рода продукция } \\
\text { с изображением героев сериала широко представлена } \\
\text { в магазинах по всей стране, и часть стоимости любых } \\
\text { товаров с летающими зверями идет на лечение детей. }\end{array}$ & $\begin{array}{l}\text { Санкт-Петербург } \\
\text { 2002, flyani.ru/fund. } \\
\text { html }\end{array}$ \\
\hline $\begin{array}{l}\text { Проект } \\
\text { «Лыжи } \\
\text { мечты» }\end{array}$ & $\begin{array}{l}\text { Создан для того, чтобы дать возможность всем } \\
\text { людям с особенностями здоровья заниматься } \\
\text { терапевтическим спортом для физической, } \\
\text { психологической и социальной реабилитации. Цель - } \\
\text { построить по всей стране систему терапевтического } \\
\text { спорта, предполагающую круглогодичные занятия } \\
\text { спортом на базе действующей инфраструктуры. } \\
\text { Распространить инновационный инклюзивный подход } \\
\text { к лечению людей с проблемами неврологического } \\
\text { спектра и другими ограничениями здоровья с трех лет } \\
\text { без верхних возрастных ограничений. }\end{array}$ & $\begin{array}{l}\text { Москва, } 2014 \\
\text { dreamski.ru/ }\end{array}$ \\
\hline
\end{tabular}

\section{Baikal Research Journal}

электронный научный журнал Байкальского государственного университета 
Эти проблемы хорошо известны не только для тех людей кто непосредственно погружен в данную деятельность, но представителям власти, ответственным за принятие соответствующих решений. Большие ожидания экспертное сообщество и практики социальной работы связывают также со вступлением в силу с 1 января 2017 г. особого правового статуса социально-ориентированных НКО. Позитивным для развития социального франчайзинга в России можно также считать и тот факт, что в недавнем выступлении Президента РФ В. В. Путина на форуме Общественной палаты «Сообщество» прозвучали важные предложения о необходимости скорейшего формирования системы новых льгот и преференции для социально-ориентированного бизнеса (аналогично малому бизнесу) и предоставлении ему преимуществ при получении государственной поддержки ${ }^{14}$.

По результатам исследования можно сделать следующие выводы. Современному обществу крайне важно и необходимо соединение ресурсов государства, бизнеса и частных лиц в решении многих социально-экономических проблем, выравнивания социальной структуры общества, снижения его дифференциации по уровню доходов и благополучия в целом. История такого взаимодействия уходит в далекое прошлое, она хорошо известна и в России, и за рубежом. По данным официальной статистики социально-ориентированный бизнес и ГЧП дают до $10 \%$ европейского ВВП и 6\% рабочих мест в Европе. Эти значения говорят о высоком социально-экономическом потенциале данного направления для России. Анализ показал, что социальному предпринимательству можно и нужно многому учиться у бизнеса. В частности, социальный франчайзинг объединяет в себе большое количестве положительных черт своего коммерческого аналога. При этом он не только помогает нуждающимся, обеспечивает трудоустройство и обогащает общество талантами, но и позволяет весьма успешно решать многие серьезные социальные проблемы современного общества.

\section{Список использованной литературы}

1. Сколько стоит Россия / И. А. Николаев, С. В. Артемьева, А. М. Калинин, И. Е. Шульга. - М. : Экономика, 2004. - 400 с.

2. Алиев И. М. Экономика труда. Теория и практика : учеб. для бакалавров / И. М. Алиев, Н. А. Горелов, Л. О. Ильина. - 2-е изд., перераб. и доп. - М. : Юрайт, 2014. - 670 с.

3. Варнавский В. Г. Партнерство государства и частного сектора: формы, проекты, риски / В. Г. Варнавский. - М. : Наука, 2005. - 315 с.

4. Холодная Н. Д. Государственно-частное партнерство - новый тип отношений в российской экономике / Н. Д. Холодная // Вопросы государственного и муниципального управления. - 2009. - № 2. - С. $42-56$.

5. Особенков О. М. Альянс государства и капитала : монография / О. М. Особняков, М. В. Щегорцов. - М. : Тип. «Новости», 2011. - 328 с.

6.Мошкова Л. Е. Государственно-частное партнерство: проблемы, проекты и риски / Л. Е. Мошкова // Региональная экономика и управление. - 2012. - № 2. - С. 91-100.

7. Ганжа И. В. Эволюция государственно-частного партнерства на различных этапах развития государства / И. В. Ганжа, Р. А. Набиев // Вестник Астраханского государственного технического университета. Сер.: Экономика. - 2012. - № 2. - С. 9-20.

8. A Practical Guide to PPP in Europe / M. Button (ed.). - Working, City \& Financial Publ., 2006. $-270 \mathrm{p}$.

9. Бугров А. В. Государственный банк и биржевые синдикаты в России / А. В. Бугров // Экономическая история. Ежегодник. 2001. / отв. ред. Л. И. Бородкин. - М. : РОССПЭН. 2002. - С. 35-46.

10. Ватутин С. Клонирование бизнеса. Франчайзинг и другие модели быстрого роста / С. Ватутин, М. Тришин. - СПб. : Питер, 2012. - 192 с.

11. Jarkina V. Franchising: in Theory and Practice / V. Jarkina. - LAP LAMBERT Academic Publ., 2010. - 168 p.

${ }^{14}$ URL: https://rg.ru/2015/06/23/stenogramma.html.

\section{Baikal Research Journal}

электронный научный журнал Байкальского государственного университета 
12. Бурменко Т. Д. Франчайзинг: сущностные характеристики и его применение в сфере услуг [Электронный ресурс] / Т. Д. Бурменко // Известия Иркутской государственной экономической Академии (Байкальский государственный университет экономики и права). 2011. - № 6. - Режим доступа: http://eizvestia.isea.ru/reader/article.aspx?id=14032.

13. Развитие российского общества: социально-экономические и правовые исследования / О. В. Батурина [и др.] ; под ред. М. А. Винокурова, А. П. Киреенко, С. В. Чупрова. M. : Наука, 2014. - 622 с.

14. Bishop W. A Biobibliography of Florence Nightingale / W. Bishop, S. Goldle. London, 1962. - $132 \mathrm{p}$.

15. Современные информационно-телекоммуникационные технологии в управлении социально-экономическими системами / А. П. Суходолов, Т. Г. Озерникова, В. В. Братищенко [и др.] ; под общ. ред. А. П. Суходолова. - Иркутск : Изд-во БГУЭП, 2013. - 196 с.

\section{References}

1. Nikolayev I. A., Artemyeva S. V., Kalinin A. M., Shulga I. E. Skol'ko stoit Rossiya [How much Russia costs]. Moscow, Ekonomika Publ., 2004. 400 p.

2. Aliyev I. M., Gorelov N. A. Ilyina L. O. Ekonomika truda. Teoriya i praktika [Labor Economics. Theory and Practice]. 2 ${ }^{\text {nd }}$ ed. Moscow, Yurait Publ., 2014. $670 \mathrm{p}$.

3. Varnavsky V. G. Partnerstvo gosudarstva i chastnogo sektora: formy, proekty, riski [Partnership of state and private sectors: forms, projects, risks]. Moscow, Nauka Publ., 2005. $315 \mathrm{p}$.

4. Kholodnaya N. D. State-private partnership - a new type of relations in Russian economy. Voprosy gosudarstvennogo i munitsipal'nogo upravleniya = Public Administration Issues, 2009, no. 2, pp. 42-56. (In Russian).

5. Osobenkov O. M., Shchegortsov M. V. Al'yans gosudarstva i kapitala [Alliance of state and capital]. Moscow, Novosti Publ., 2011. 328 p.

6. Moshkova L. E. State-private partnership: problems, projects and risks. Regionalnaya ekonomika $i$ upravlenie = Regional Economics and Management, 2012, no. 2, pp. 91-100. (In Russian).

7. Ganzha I. V., Nabiyev R. A. Evolution of at various stages of state development. Vestnik Astrakhanskogo gosudarstvennogo tekhnicheskogo universiteta. Seriya: Ekonomika = Bulletin of Astrakhan State Technical University. Series: Economics, 2012, no. 2, pp. 9-20. (In Russian).

8. Button M. (ed.). A Practical Guide to PPP in Europe. Working, City \& Financial Publ., 2006. $270 \mathrm{p}$.

9. Bugrov A. V. State bank and exchange market syndicates in Russia. In Borodkin. L. I. (ed.). Ekonomicheskaya istoriya. 2001. [Economic History. 2001]. Moscow, ROSSPEN Publ., 2002, pp. 35-46. (In Russian).

10. Vatutin S., Trishin M. Klonirovanie biznesa. Franchaizing $i$ drugie modeli bystrogo rosta [Business cloning. Franchising and other models of fast growth]. Saint Petersburg, Piter Publ., 2012. 192 p.

11. Jarkina V. Franchising: in Theory and Practice. LAP LAMBERT Academic Publ., 2010. $168 \mathrm{p}$.

12. Burmenko T. D. Franchising: essential characteristics and functioning in service industry. Izvestiya Irkutskoi gosudarstvennoi ekonomicheskoi akademii (Baykalskiy gosudarstvennyy universitet ekonomiki $i$ prava) $=$ Bulletin of Irkutsk State Academy of Economics (Baikal State University of Economics and Law), 2011, no. 6. Available at: http://eizvestia. isea.ru/reader/article.aspx?id=14032. (In Russian).

13. Baturina O. V. et al.; Vinokurov M. A., Kireyenko A. P., Chuprov S. V. (eds). Razvitie rossiiskogo obshchestva: sotsial'no-ekonomicheskie $i$ pravovye issledovaniya [Russian Society Development: Socio-Economic and Legal Research]. Moscow, Nauka Publ., 2014. 622 p.

14. Bishop W., Goldle S. A Biobibliography of Florence Nightingale. London, 1962. $132 \mathrm{p}$.

15. Sukhodolov A. P., Ozernikova T. G., Bratishchenko V. V. et al. Sovremennye informatsionno-telekommunikatsionnye tekhnologii $v$ upravlenii sotsial'no-ekonomicheskimi sistemami [Modern Information and Telecommunication Technologies for Social and Economic Management]. Irkutsk, Baikal State University of Economics and Law Publ., 2013. 196 p.

\section{Baikal Research Journal}




\section{Информация об авторах}

Недоспасова Ольга Павловна - доктор экономических наук, профессор кафедры экономики Института социально-гуманитарных технологий, Национальный исследовательский Томский политехнический университет, 634050, г. Томск, пр. Ленина, 30, e-mail: opnedospasova@tpu.ru.

Ефрелова Екатерина Александровна - студент, Национальный исследовательский Томский политехнический университет, 634050, г. Томск, пр. Ленина, 30, e-mail: kat.efremovaa.98@gmail.com.

Сондор Александра Алексеевна - студент, Национальный исследовательский Томский политехнический университет, 634050, г. Томск, пр. Ленина, 30, e-mail: sondor.a.a@icloud.com.

Хайдарова Карина Ильдаровна - студент, Национальный исследовательский Томский политехнический университет, 634050, г. Томск, пр. Ленина, 30, e-mail: rishakh@mail.ru.

Недоспасов Анатолий Александрович - студент, Северский технологический институт - филиал Национального исследовательского ядерного университета «МИФИ», 636036, г. Северск Томской области, просп. Коммунистический, 65, e-mail: onotole.great@yandex.ru.

\section{Authors}

Olga P. Nedospasova - Doctor habil. (Economics), Professor, Chair of Economics, Institute of Social and Humanitarian Technologies, Tomsk National Research Polytechnic University, 30 Lenin Av., 634050, Tomsk, Russian Federation; e-mail: opnedospasova@tpu.ru.

Ekaterina A. Efremova - Student, Tomsk National Research Polytechnic University, 30 Lenin Av., 634050, Tomsk, Russian Federation; e-mail: kat.efremovaa.98@gmail.com.

Aleksandra A. Sondor - Student, Tomsk National Research Polytechnic University, 30 Lenin Av., 634050, Tomsk, Russian Federation; e-mail: sondor.a.a@icloud.com.

Karina I. Khaidakova - Student, Tomsk National Research Polytechnic University, 30 Lenin Av., 634050, Tomsk, Russian Federation; e-mail: rishakh@mail.ru.

Anatoly A. Nedospasov - Student, Seversk Technological Institute, «MIFI» National Research Nuclear University, 65 Komsomolsky Av., 636036, Seversk, Russian Federation; e-mail: onotole.great@yandex.ru.

\section{Библиографическое описание статьи}

Франчайзинг для социальных проектов: чему можно научиться у бизнеса? / О. П. Недоспасова, Е. А. Ефремова, А. А. Сондор, К. И. Хайдарова, А. А. Недоспасов // Baikal Research Journal. - 2017. - T. 8, № 1. — DOI: 10.17150/2411-6262.2017.8(1).17.

\section{Reference to article}

Nedospasova O. P., Efremova E. A., Sondor A. A., Khaidarova K. I., Nedospasov A. A. Franchising for social projects: what can we learn from business? Baikal Research Journal, 2017, vol. 8, no. 1. DOI: 10.17150/2411-6262.2017.8(1).17. (In Russian).

\section{Baikal Research Journal}

